\title{
A Utopian Way of Thinking about Work: Tracing William Morris' Ideas on the Concept of Work
}

\author{
Selcan Peksan
}

\begin{abstract}
Social theories present a wide range of criticism regarding the modern organization of work, yet little on the nature of humans and what an ideal concept of work would be. Favoring a utopian way of thinking about work, this paper inspects William Morris' understanding of work and the basic dynamics of work organization in his vision of the society of the future. This article has chosen to perform an in-depth analysis of his utopian novel News from Nowhere due to the transformation of work laying at the core of the book. By tracing the key patterns of work in Morris' future utopia which he called Nowhere, this paper proposes the concept of work that articulated in Morris' thought as a means of gaining an alternative model regarding the recent debates about the future of work. In particular, the paper scans Morris' arguments on labor to demonstrate how Morris' view presents an inspiring approach for our era. This hopefully opens up the prospect of thinking about the ideal work of the future one wants to achieve.
\end{abstract}

Keywords: Utopia, William Morris, News from Nowhere, concept of work, pleasurable work, attractive labor, meaning of work, future of work.

Öz: Sosyal teoriler, modern çalışma örgütlenmesine dair geniş bir eleştiri yelpazesi sunmaktadır. Buna karşın insan doğası ve ideal çalışmanın nasıl olabileceğine dair tartışmalar sınırlı kalmıştır. Çalışma olgusunu ütopik bir bakış açısıyla ele almayı öneren bu makale, William Morris'in çalışma kavramsallaştırmasının başlıca argümanlarını ve gelecekteki toplum vizyonunda çalışma örgütlenmesinin temel dinamiklerini konu almaktadır. Morris'in eserlerinden ütopik romanı Hiçbir Yerden Haberler, özünde çalışmanın dönüşümünü barındırması sebebiyle, derinlemesine incelenmek üzere seçilmiştir. Morris'in ütopyası olan Hiçbir Yer'deki çalışmanın başlıca özellikleri izlenerek, işlerin geleceği ile ilgili güncel tartışmalara alternatif bir perspektif geliştirilmesi amaçlanmıştır. Gelecekte ulaşmak istediğimiz ideal çalışmanın nasıl olabileceği üzerine yeni arayışları tetiklemesi umuduyla Morris'in çalışmaya ilişkin görüşlerinin çağımıza ilham veren bir yaklaşım sunduğu iddia edilmektedir.

Anahtar Kelimeler: Ütopya, William Morris, Hiçbir Yerden Haberler, çalışma kavramı, zevkli çalışma, çekici iş, çalışmanın anlamı, çalışmanın geleceği.

* This article is an extended version of the paper presented at the 2nd Erasmus International Academic Research Symposium, October 11-13, 2019; Paris, France. (2019, October 11-13).

@ Ph.D, Research Assist., Istanbul University, selcan.peksan@istanbul.edu.tr 


\section{Introduction}

Labor is one of the oldest and most central areas of human life. People have been working to create their living spaces, protect themselves, and survive from the moment they exist in the world. However, the meaning and nature of work have changed significantly throughout history. Work in its broadest sense can be described as the energy, effort, or toil spent for a particular purpose (Thomas, 1999, pp. xiii-xiv). Nevertheless, the use of physical, mental, or emotional power for a particular purpose is involved in most human activities. Describing an effort as work depends on the organizational structure of the society. The meaning and value of the concept of work are determined by the norms, beliefs, and values of societies and as a result have changed in parallel with the economic developments in the historical process.

The institutional and conceptual frameworks of work as it is understood today were constructed by modern capitalist societies after the Industrial Revolution. Since then, work as a word implies a concept, character, and function unique to it. First of all, the conceptual framework of work in the modern world is limited to market-driven practices and excludes all kinds of unpaid human activities (Levitas, 2001, p. 450). As Cleaver put it, labor in the modern world is a capitalist category. Secondly, capitalist work is the organizing principle of people's lives and society (Cleaver, 2001, p. 147). Capitalist work as a term refers to a specific form of labor that is paid monetarily. This form of labor defines not only individuals' lives but also institutions as the organizing principle of social life; it forms the basis of socio-cultural integration and interdependence (Dinerstein \& Neary, 2001, p. 13). In other words, starting with modern capitalist societies, work implies the paid activities for producing goods, services, and information. Its productivity depends on its economic value. From this period on, work is seen not only as necessary for sustaining life but also as the basis of social structures and relations, the source of value and assets, the main form of productive activity work (Méda, 2010, pp. 26-33), and the unquestionable means of social progress. Thus, while capitalist work has been regarded as a natural category expressing the sole purpose of human life and individual existence, all other types of labor have been led to a marginal position (Peksan, 2021, p. 16).

Work has also theoretically been accepted as central to both social and cultural life by social scientists from different perspectives, including Adam Smith, ${ }^{1}$ Karl

1 The turning point for the meaning of work was its use as an abstract term in political economy. The conceptualization of work in economic theories is mainly grounded in Adam Smith's work. Smith attached fundamental importance to labor by conceptualizing it as the sole factor determining the value of goods. In The Wealth of Nations (1776, 2007), one of the most fundamental texts from economic theories, Smith emphasized the main resource for the welfare of a country to be labor power (Chapter V, p. 28). 
Marx, ${ }^{2}$ Max Weber, and the Chicago School throughout the $18^{\text {th }}, 19^{\text {th }}$, and $20^{\text {th }}$ centuries (Vallas, 2012, p. 1). Classical economists accepted work as an inconvenient action that people want to be free of but also as an obligatory necessity for sustaining individual and social existence and hence a phenomenon to bear (Spencer, 2009, p. 97). On the other hand, the classical social theories of the $19^{\text {th }}$ century commonly conceptualized work as the sole means of realizing the self and as reflecting the most creative and original power of humankind. While glorifying this ideal, which had been in great contrast with the conditions of industrial capitalism at the time, classic social theorists focused on the negative consequences of industrialization and the critique of capitalist work (Méda, 2010, pp. 90-101) yet refrained from elaborating on what ideal work is. Even Marxism, which idealizes a working concept in which human beings can reflect their creative power and thus make their existence meaningful as the essence of labor, has no details about the basic features of the work to be achieved after capitalist society (Marx, 1973, pp. 544-545; 1984, p. 820; 2004, p. 717).

This article sets out from the claim that utopian thought provides an important opening on the subject of the concept of ideal work, which remains incomplete in social theories. Indeed, theories on an ideal society in which people can be freed from the difficulty and necessity of work have always been labeled as utopic and romantic discourses. Nevertheless, utopias can be claimed to perform an important function in terms of forming the perspective required from social change. As Mannheim (2008, p. 58) put it, utopian thought aims to design the change of the present rather than to deal with the actual. In this sense, it can be used as an action guide. From this point of view, this article has emerged from a curiosity mainly directed toward the process of ideal work/labor in utopias. Starting from Thomas More, utopian literature was scanned and William Morris's approach was chosen to be covered in this article. The reason why Morris was chosen from the broad utopian literature is that, beyond focusing just on the critique of his time, he also centered the fundamental transformation of work in the construction of his ideal social order, and by so doing had designed a concept of work that transcends the boundaries of the conceptualization of work in the modern world. This article's main issue is to reveal the basic dynamics

2 Adam Smith's view that value is created entirely by labor in primitive societies lacking private property and capital accumulation was expanded upon by David Ricardo and Karl Marx. According to the labor-value theory, labor is always the only factor that creates value (For more details, please see Bocutoğlu, 2012; Also, for a brief review of the concept of work in classical social theories, see Peksan, 2021, pp. 108-138). 
of the ideal/utopian work in Morris' thoughts. In this way, the study aims to open a new discussion area for the present where the end of work is announced following the development of artificial intelligence and robotic technologies.

\section{William Morris' Concept of Work: Work as Joy, True Dignity and Pride in Living}

William Morris (1834-1896) was a socialist, designer, architect, writer, journalist, and poet (McCarthy, 2004). As a versatile and productive person, Morris had the pleasure of working in various areas of expertise. Accordingly, his thoughts on work reflected his personal experience. In addition to his personal working experience, four main influences affected Morris' conceptualization of work: the inspiration of Utopian socialists, in particular Charles Fourier's conception of attractive labor; his affinity toward the Marxist political tradition; Morris' understanding and knowledge of medieval craftwork; and John Ruskin's critical views about industrial production's advantage over arts and handcrafts (Stirling, 2002, pp. 130-131).

In this framework, the first step in Morris' conceptualization of work was to adopt Charles Fourier's views ${ }^{3}$ on making work attractive and providing freedom for people to reflect their true identities. By tracing Fourier's concept of attractive work, Morris believed labor to be inherently attractive (Mellor, Hannah, \& Stirling, 1988, pp. 9-10), and hence the principal theme of work should be joy. In a social organization governed by desires, people would be drawn to the different types of work they enjoy, and work indeed would be nothing more than a pleasure. In this sense, Morris can be claimed to have been directly influenced by Charles Fourier's conceptualization of attractive work while also himself designing work as an attractive activity in human life (Spencer, 2009, p. 98).

According to Morris, what prevented people from seeing work as a source of enjoyment was not their nature but a specific social system (i.e., the capitalist organization of work) that had caused the alienation of workers (in the Marxist sense; Stirling, 2002, p. 133). In this context, Morris' idealization of work as a reflection the necessity of making work turn into something attractive rather than a driving necessity. The key to making work enjoyable is to free the passions. According to Fourier, work should be organized in such a way that it can be included in the game of attraction and thus be seductive, inspiring, and enjoyable for individuals. The actual transformation of work involves transforming work itself into a need and a pleasure (Beecher \& Bienvenu, 1972, pp. 32-49; Fourier, 1972, p. 148; Granter, 2009, pp. 35-39). 
of human existence parallels Marxist thought. Rejecting the concept of work as a cause of suffering, Morris argued that work became unpleasant only under capitalist relations. In other words, capitalism is what makes work the useless toil of workers. Influenced by Marxist thought, Morris constructed his analysis on the distinction of work under capitalism (bad work) and work as the essence of man (good work), as detailed in his essay Useful Work Versus Useless Toil (1884). To Morris, the organization of work represents the class divisions of capitalism, and therefore the production of surplus value implies the subjugation and exploitation of labor. People work just to survive, not for any pleasure in the work they do. He defined this type of work as slavery work. In essence, however, he was assuming that human nature tends to release its creative and productive forces, and in a social system that allows people to pursue their desires, work would become a set of actions that people enjoy (Morris, 1884). Because Morris' thoughts on work are deeply rooted in the Marxist class analysis and the key to the criticism of the capitalist labor process (Stirling, 2002, p. 129), he claimed that, due to the capitalist idea of work having been structured to maximize profit, using both mechanization and the division of labor for this purpose had caused alienation. Hence, the workers have no control over either the processes or the products of their labor. Under these circumstances, working was not only unpleasant, and Morris also concluded that degradation of human life and the outcomes of these process (i.e., the goods produced) were characterized by a utilitarian ugliness (Morris, 1888). As such, an emphasis was placed on the interdependency of processes and outcomes. The division of labor also meant that workers were being "permanently degraded into machines [by being] driven to work in a mechanical, down-hearted kind of way;" as a consequence, the degradation of humanity was the outcome of capitalism (Morris, 1881).

Contrary to the alienated nature of the capitalist organization of work, Morris thought that the unity of theory and practice should be at the core of the struggle to change the world. He believed in the significance of doing and dreaming as a whole (Browne, 2018, p. 4). The worthy work of covering theory and practice reflects not only the energies of mind, soul, and the body but also memory, imagination, and even the inherited accumulation (Morris, 1884). This formula conveys the other fundamental aspect of Morris' thought: the importance of craftwork.

In his early writings as outlined above, Morris had made a dual conceptualization of work, with good work as a foundation for happiness and bad work as capitalist work. Updating this categorization in Socialism from the Root Up, Morris and Belfort Bax (1886) proposed three forms of work in a society. The first kind they acknowledged 
as the necessary and repellant work that commonly revolts people but needs to be done (e.g., garbage collecting, sewer cleaning, coal mining). Morris and Bax expected technological advancements to transfer the majority of these rough occupations to machines and the rest to be undertaken by volunteers who possess a sense of duty to the community. The second type of work they categorized also involves certain hardships that could also be shared between machines and volunteers as a social duty yet simultaneously still be pleasurable to some people. Finally, there are works involving arts and crafts, the type of work to which Morris and Bax attached great importance. They accepted all kinds of craftsmanship as art in terms of the pleasure of creating (Morris \& Bax, 1886). As Morris' definition of work is essentially synonymous with pleasure, Morris under the influence of Ruskin considered the only way to have enjoyment in labor practices would be to express creative forces through arts and craftworks. In other words, art is the reflection of human pleasure in labor. This also exposes the creative forces in society (Hale, 2003, p. 269). Morris had been involved with arts and crafts throughout his life. Bearing in mind his passion for making and creating things, Morris' theory can be stated as having been mainly constructed over the types of work that involve arts and crafts and that he had tried to design a society that could meet the conditions for the possibility of creative production for all.

Morris believed that work in the capitalist system must change in all its aspects and that the starting point for transforming work would be to not only eliminate wage labor but also abolish the division of labor. By abolishing the division of labor between physical and mental activities, genders, and art and labor in particular, Morris argued for the possibility of being able to participate in various forms of work and developing humanity's superior capacities for everyone. Once such a transformation is implemented, work would become the real foundation of happiness, satisfaction, pleasure, and self-realization rather than an object of toil and coercion (Browne, 2018, pp. 1-4). Thus, the reorganization of work under socialism should focus on giving workers back the power over their own lives by allowing free expression of the artistic impulses Morris had claimed to be innate to humanity. Because creative instincts are natural to humankind, fulfilling this natural urge would allow workers to affirm their own humanity through the very practice of labor. Because "The ethics of the artist bid him put as much of himself as he can in every piece of goods he makes," Morris (1889) contended that workers would implant the very soul and thought of humankind into the product (Hale, 2003, p. 270). In this way, reflecting the human soul and thought allows the outcome of the labor process, being a pleasure in itself, to become a piece of art (Stirling, 2002, p. 133). As Drinkwater (1912) stated, art was the most important human activity, one that Morris placed at the highest level. 
Accordingly, his social theory and arguments were based on making artistic activity accessible to all people because he saw artistic creation as the ability to be one's self and as the source of the character he accredited as the supreme need of humans. What Morris felt with all the energy in his being was that the most important need in the world was a character that reflection being itself in the artistic creation. Therefore, he had looked for ways to bring pleasure back to work so that people could just take a step toward their true honor, dignity, and pride in their lives by having this character (Drinkwater, 1912, pp. 198-201). Morris clearly stated, "The properly organized labor of all men who make anything; that must at least be a mighty instrument in the raising of men's self-respect, in the adding of dignity to their lives (Morris, 1881)." In summary, Morris conceptualized work as a source of pleasure and pride and as a field in which humans reflects their own individuality. He elaborates in his book News from Nowhere (1908) the functioning of work as joy and the source of true dignity.

To be able to determine Morris' opinions on work, his views should also be mentioned on the relationship between nature and humanity, one of the most striking features of Morris' arguments. As is known, in $19^{\text {th }}$ century thought, labor had been defined under the influence of Darwinism as the nature-transforming activities in the human struggle against nature, whereas Morris' thought showed a labor process that was compatible with nature (Hale, 2003, p. 252). In response to the perception of capitalist work that positioned people opposite nature, he emphasized the harmony between the human race and nature. Because of his approach to nature, Morris is considered one of the first eco-socialist thinkers to have proposed a vision prioritizing ecological regeneration and sustainability (Macdonald, 2004, p. 287).

\section{The Main Features of Work in Morris' Utopian Future}

The most important aspects of Morris' views on work are outlined above. This section discusses Morris' book News from Nowhere, which was published in 1890, to examine his thoughts on work in more detail and to deepen his conceptualization of work. The reason why the book is handled separately here is that clear examples are encountered of how work would function in the society Morris had dreamed of for the future. The aim is to trace Morris' views about work as well as art, architecture, environment, and aesthetics by exploring the main features of work in the utopian society described in News from Nowhere.

The concept of utopia is a controversial issue in the social sciences. Utopian as a term is a belief about a future in which the present has essentially been transcended. 
It is a notion that life, work, and even love in the future may differ from what is currently known (Jacoby, 1999, p. xii). A utopia points to an ideal society. As Kumar (2005) put it, a utopia is a near-perfect society and place just beyond the truth but not inaccessible to humanity. A utopia is a text that transcends a reformist social or political handbook. Despite always exceeding what is directly applicable, a utopia is never just a dream. The value of a utopia is not in its current applicability but in its relation to the possible future. It is to jump over the present reality by describing an applicable social situation that is attractive and desired to exist (Kumar, 2005, pp. 9-12). The historian Russell Jacoby points out that two different forms of utopian thought exist: blueprint utopians and iconoclastic utopians. The blueprint utopians construct the future by detailing all aspects of life in the ideal future society. They offer guidance on everything from eating habits to dialogue topics, whereas iconoclastic utopian tradition thought opposes established institutions and traditions (Jacoby, 2005, p. xv). As such two basic functions of utopias can be mentioned. The first of these presents the image of an ideal social order thought to be realized in the future. One can argue this kind of future imagining to be one of the most important drivers of social development. The second function can present a serious critical approach to the order from which the utopia proceed. This critical perspective is the description of the groundwork to be overcome for the ideal to be reached. News from Nowhere as discussed within the scope of this article presents both a critical perspective of its era and a detailed account of the ideal future society.

Due to the future societal framework drawn in News from Nowhere, Morris is widely regarded as a pioneer who challenged industrial capitalism (Kumar, 2005, p. 164) and drew a road map of what an eco-socialist future could be like (Kumar, 1993, p. 72). E.P. Thompson (1976, p.682) described Morris as one of the developers of socialist life in a communist society. News from Nowhere, however, wasn't proposed as a literal representation of a communist future; as E.P. Thompson (1976, pp. 695-696) pointed out, what underlies the artistic power and uniqueness of the book is that it is a scientific utopia. By standing in opposition to the literature on industrial capitalism and also to the Victorian tradition of fiction, the book is claimed to be an anti-novel, a utopian romance (Brantlinger, 1975, p. 35) in which the story begins in the $19^{\text {th }}$ century with six people having a debate about what would happen after the Revolution and what a fully developed society would be like. After this discussion, one of them (William) returns home unhappily. Before falling asleep, he says, "If I could but see a day of it... If I could but see it!" (Morris, 1908 , p. 5). He falls asleep in the $19^{\text {th }}$ century and wakes up in an innocent and happy future of 2102 where people live in peace and tranquility. As a guest in this 
future, William gets involved in the public, meets people, and tries to understand how society functions.

News from Nowhere is a depiction of a utopia in which work has been fundamentally changed and completely reorganized in a way where people have been liberated from alienation. They have an integrated and artful life in a society where every individual has a part. In this utopian society, the emphasis is on attitudes rather than conditions (Freeman-Moir, 2011, pp. 202, 214); human social relations are based on cooperation and mutual regard rather than competition. It is a wealthy society where people are not in need; therefore, they are both generous and selfless toward one another (Hale, 2003, p. 271). It has no institutions such as state, market, religion, marriage, private property, or authority. The society is one in which free and equal individuals are responsibly interconnected. This takes the form of a gift economy and mutual exchange system. Every person devotes themselves entirely to society through their labor while at the same time, the society provides all their needs (Browne, 2018). At the center of the transformation that has eliminated all these capitalist institutions is labor's radically different organization. In other words, the trigger for all other transformations in this developed society had been the transformation of the concept of work. Instead of being an obligatory burden, work has become one of the primary pleasures of life. The book has many details regarding how the utopia of Nowhere functions, but it places the organization of labor at the fore. The following section examines the main features regarding work in News from Nowhere.

\section{Abolishing Capitalist Work Relations and Market Systems: Labor as a Source of Pleasure}

The first thing one understands about the transformation of work is the breaking of the link between work and wage/income. No exchange system exists for purchasing workers' time or commodities. The concept of paid work has disappeared. At the very beginning of the adventure, William wakes up as a guest in the future. He goes to the banks of the Thames. When the boatman Dick, who will later be William's guide, brings him back to the shore after a short trip on the river, William attempts to pay him for his service; Dick, laughing at him as if it's the funniest thing to get something for his work, replies, "And you see this ferrying and giving people casts about the water is my business, which I would do for anybody; so to take gifts in connection with it would look very queer" (Morris, 1908, p. 12). This is the first leg 
of the transformation of labor in this utopia: Paid labor has no form; there is no monetary value for work. Commodities are not sold but can be obtained for free.

Because Nowhere is a society without money, there is no reward for work in monetary terms, just the joy of work itself (Stirling, 2002, p. 137). Trying to understand this issue as the story progresses, William asks Dick's grandfather, Hammond, how they made people work so hard without any reward for working. "The reward of labor is life. Is that not enough?" replies Hammond (Morris, 1908, p. 91). The essence of Hammond's argument is the understanding that work generates life in the sense that it provides the material conditions of nature while at the same time embodying the activity of human life (Braham, 2015, p. 54). The reader sees that, once work is no longer conceptualized as toil or suffering, the need for a reward disappears. There is no such thing as avoiding work or needing a reward for doing better work because work is a pleasure of creation that integrates life. Moreover, work is not defined as a compulsory action to satisfy needs or to sustain life.

Morris tries to prove that once work turns into a source of happiness for individuals, all other changes in society become possible. But what are the bases for perceiving work as pleasure? The reasons that make work enjoyable are explained by covering three of the types of work proposed by Morris and Bax (1886). In the first case, work is an art; as an activity that appeals to emotions, work gives conscious pleasure in itself. In the second case, work takes a form of mechanical work that can be experienced as a tasteful habit, and the third case involves the hope of gaining dignity and wealth at the end of work, which turns work into a pleasant excitement even if the work itself is unenjoyable (Morris, 1908, p. 92). In this way, Morris attempts to prove that working is a fun activity regardless of type, and hence no need for a monetary reward accompanies work.

Regarding this issue, two important sections of the book should be noted. The first is the part where William runs into a group of people who are building a house. They refuse to take part in the harvest when Dick invites them. Because they are concentrated on their work and it is so attractive to them, they don't want to leave it even to have fun or talk to guests. The satisfaction of creation leads them to work at their best. The second example is the part where William runs into a group of road builders along the way. He observes that all the road workers are talking and laughing; they appear completely unbothered by the hardship of the work they do. Explaining to William, Dick emphasizes the pleasure of manual labor and the positive effects building roads has on the body. Work is perceived as a sport in this example. Dick says, "They are in luck today: it's a right down good sport trying how much pick work one can get into 
an hour... It is good to work for hardening the muscles and I like it... Everything seems like a joke when we have a pleasant spell of work on" (Morris, 1908, p. 49). Therefore, not just artistic work but also necessary work is experienced as a game and a source of happiness rather than a painful toil. However, Stirling (2002) points out that neither of these examples precisely reflects work that is necessary but repulsive. Throughout the book, the reader encounters no one occupied with works like cleaning sewers or coal mining. This is because Morris and Bax assume some of these bad jobs will have simply been abolished. The road builders voluntarily undertake work categorized as arduous but necessary and enjoy it. The work of whose who refused to join the harvest, however, provides an example of work as art (Stirling, 2002, p. 133). In this sense, an "individuated work-pleasure offer" is present in Nowhere (Camlot, 2018, p. 57).

The reader is told that, once the capitalist market system disappears, people produce only for specific purposes. A purpose might be related to either the basic material needs of the society or a personal impulse. The highlight here is that capitalist market relations need more labor power to produce unnecessary goods. On the contrary, troublesome works have been transferred to machines, and the production of less-necessary commodities has simply been abandoned or shared in Nowhere. In this way, each citizen has the opportunity to engage in a job that suits them and is appealing. For this reason, Kumar (2005, p. 164) suggested that Morris had not completely rejected industry. However, by strictly reinstating what is necessary, new targets determine the framework of production based on aesthetic pleasure and harmonious development. In this reorganized and reoriented structure of production, material growth has been limited. The view is that the continuous increases in production and continuous market expansions cause people to sacrifice everything meaningful about their lives and destroy the natural order.

\section{Autonomy in Work Choice: Attractive Labor}

The concept and organization of work in Nowhere differs from capitalist work in many ways; however, perhaps the most significant feature as noted is the existence of attractive labor. Throughout the book, William meets people who are engaged in arts and crafts and who enjoy what they do; they are engaged in different activities that are enjoyable and attractive to them.

The part about those who refused to help with the harvest just because they were focused on their semi-artistic work of house building is a significant example of the self-directed character of work in News from Nowhere. Refusing to leave their duty 
to build a house in favor of taking a part in the required work of harvesting shows that any work can be opted out of as others will happily take them on. As such, the decision to work belongs to the individual and no one else (Stirling, 2002, p. 133). The reader sees that people choose their activities with complete autonomy. They can discover the areas they are good at because they do what they like. They are encouraged to make the productions they want to make.

Morris (1885, p.49) believed that citizens would naturally go on to do different types of work because "people's abilities are as varied as their faces." Therefore, this matter of adjusting work to people's capabilities and not the capitalist system's way of adjusting people's ability to the job may be the most significant turnaround of the current organizing of labor (Stirling, 2002, p. 136). "It is said that in the early days of our epoch there were a good many people who were hereditarily afflicted with a disease called Idleness because they were the direct descendants of those who in the bad times used to force other people to work for them" (Morris, 1908, p. 40). In Nowhere, "People found out what they were fit for, and gave up attempting to push themselves into occupations in which they must need fail" (Morris, 1908, p. 71). Following this belief, job selection and preference are seen to be completely autonomous in Nowhere. The reader sees a society where everyone works enthusiastically as a result of leaving it to individual preference. Productivity is exalted with no emphasis on social benefit in this production. For example, if a person in Nowhere wishes, they can spend all their time writing novels. Nothing exists resembling the need to share works such as hay collecting and construction for general social benefit. Individual preferences and desires are at the forefront.

\section{The Unity of Arts and Craft with Work: Labor as a Life-Activity}

As one of the most unique features of Morris' conception of work, the absence of division of labor proposes an integrated view of human development and creativity (Kinna, 2000, p. 511). In Nowhere, everything is in balance, and people live in harmony; they enjoy the moments of their lives, rowing, mowing, growing things, cooking, creating, sculpting, constructing, weaving. They find happiness and satisfaction in the natural rhythm of their physical contact with life. By not only abolishing the division of labor (Browne, 2018, pp. 1,4,13) but also by not differentiating status among occupations, humanity's relationship to labor has been transformed in a way where work becomes a natural aspect of life. In this way, Morris overcomes the alienating outcomes of the industrial capitalistic organization of work. 
As a completely autonomous pleasure, labor in Nowhere is the reflection of a worker's essential being. The worker is no longer alienated from the outcome, the production process, or their labor. They don't feel miserable or unhappy. On the contrary, now they confirm themselves through their work and are free to fully develop their mental and physical energies (Braham, 2015, p. 54). The book has several examples showing that developing both manual labor and intellectual professions are possible. Depending on one's passion, a person can develop expertise in an intellectual profession while still being able to freely rotate between artistic and/or physical activities whenever they want. For example, after meeting the Guest (William), the boatman Dick quits his work to be William's guide. Dick tells him that he's got a friend who would happily take over his job while he's away. The friend normally works indoors as a weaver and a mathematician, and this man asks Dick to take over some outdoor activities (Morris, 1908, p. 13). Another person tells William about his specialization in mechanical weaving, yet at the same time he does machine printing and composing. This person also talks about his interest in mathematics and says he is also writing a history book (Morris, 1908, p. 21). These examples show that Morris tried to envisage a labor form that not only eliminates division of labor between manual and mental but one that also gives each person the chance to produce in various areas in order to develop mentally and physically.

As Kinna (2000, p. 21) notes, Morris' critique of industrialization and his proposal of elimination of division of labor are indeed key factors for the realization of attractive labor. Morris successfully analyzed the alienating results of the rigid organization of factory production, which holds the worker essentially bound to one repetitive task, and glorified the experience of craft as the most important component of eliminating alienated labor. Accordingly, Kinna stated craftmanship to be an idea central to Morris' utopian ideas. As Thompson (1976, p. 649) claimed, Morris' utopian desire was to transform capitalist society into a society of craftsmen. The craftsmen society is a system where the class hierarchy has been replaced with social equality. Hence, the most fundamental aspect of the work experience in News from Nowhere is the full development of craftsmanship applications that sustain artful work and artful life in the utopian society. With the freedom to pursue the most attractive and best suited work, each person attempts to make their work more joyful. Internal motivation is what raises the standard of excellence (Freeman-Moir, 2011, p. 224). Furthermore, the organization of craftsmanship work gives the worker control over work hours and the tools and materials for production; it connects the person not only to the product but also to their own labor. 
Even though Morris' approach can be considered as romantic medievalism, the emphasis on craftsmanship helps Morris to not only stand against the alienating consequences of capitalist production but also to establish a form of labor that reflects self-realization through the pleasure of creative work. This is how labor is conceptualized as a source of an artful and happy life. Because working in Nowhere is a pleasure and the experience of craftsmen's labor brings in more and more pleasure to the work, labor becomes an aesthetic experience, which results in art. As Morris acknowledges, "That thing which I understand by real art is the expression by man of his pleasure in labor. I do not believe he can be happy in his labor without expressing that happiness" (Morris, 1879). According to Morris, each crafted product is naturally made with care; hence, whether an object, institution, or conversation, all crafted artifacts are reflections of this care (Freeman-Moir, 2011, pp. 202-205, 214). Thus, emphasis is found in News from Nowhere on the majority of work being done by skilled craftsmen and all craftsmen being artists as they naturally bring more and more pleasure to their products. Unsurprisingly all the products and buildings are beautiful in Nowhere.

Noteworthy, beauty and attentiveness appear to be the most fundamental societal values in Nowhere. Emphasis is placed on the beauty of the architecture, nature, streetscapes, manufactured goods, clothes, and people's physical appearances. Behind the beauty of the objects produced exists the physical ability, creative thinking, and imagination used to produce them. Therefore, the beauty of the action is indicated by the beauty of the products (Kumar, 2005, p. 164). Morris' thoughts consider labor as a fundamental element of human existence; it is the way through which existence itself is generated, the way an individual's innate human desire to create is conveyed (Braham, 2015, p. 52). The beauty of products can be concluded to reflect the beauty of human nature. Moreover, beauty, elegance, and aesthetics provide citizens with dignity and self-satisfaction. Therefore, "Happiness without happy daily work is impossible" (Morris, 1908, p. 92). Consequently, one of the most striking aspects of the concept of labor in Nowhere is that each citizen has been provided with the opportunity to attain useful and creative activities and thus be happy.

\section{Labor in Harmony with the Natural World}

As an early environmentalist, Morris accepted humanity as a part of nature rather than outside of it. Contrary to the trend common in his era, he envisaged a society that harmoniously reintegrated with the natural world. Recognized as the pioneer of ecological utopia (ecotopia), News from Nowhere portrays a society that does not 
contradictorily perceive nature as a struggle to survive. The high ecological consciousness of the society manifests itself in all areas of life in Nowhere (Kumar, 2002, p. 187). The energetic people of Nowhere are “...surrounded by beautiful things of their own fashioning, and a nature bettered and not worsened by contact with mankind (Morris, 1908, p.129). A natural balance exists between nature and humanity.

Morris' views on nature can be said to be noticeably related to his conception of labor. Rather than accepting the definition of labor as all the activities transforming nature in humanity's struggle for existence, Morris recognized the importance of conceptualizing work as not only in the natural rhythm of life but also as a natural part of nature. Correspondingly, he portrayed a labor process in Nowhere that regenerates an association between humanity and nature. In this way, he also points out that nature is more than having just an instrumental value aside from defending the rights of future generations (Hale, 2003, p. 280). Thus, he should be said to have not only stood against the environmental problems caused by industrial capitalism (e.g., pollution, mass industrial waste) through his arguments on labor in harmony with nature but to have also manifested his demand for a production system with environmental awareness.

\section{Conclusion: How Can Morris' Ideas Inspire Current Debates on the Future of Work?}

This paper has provided an in-depth investigation into the dynamics of Morris' concept of work in order to open a debate on the meaning of work and propose a utopian model of how to organize work so as to form the perspective that social change needs. As detailed above, Morris had conceptualized work as a manifestation of human existence and a source of both individual and social happiness. By conceptualizing labor as a joy rather than an obligatory toil, Morris opposed the basic assumptions of classical economists and proposed an alternative. Moreover, he had elaborated on the ways to achieve social theories' idealized conceptualizations of labor. Morris' ideas, life, arts, and writings have inspired many artists and thinkers. ${ }^{4}$ With the claim that Morris' arguments are unique and powerful enough to remain relevant to the current debates of the future of work, this conclusion aims to emphasize the most inspiring aspects of his views by associating them to the current era.

4 For a list of works on Morris, see: (Kumar, 2002, xxviii-xxx) and http://www.morrissociety.org/morris/social.html. 
These days, the future of work has become one of the most popular areas of debate triggered by the technological developments of recent years such as artificial intelligence, robotic technology, 5G networks, and nano-technology. Evaluated as a potential that will affect all aspects of human life, technological developments are expected to eliminate most of the jobs in the near future and radically change the employment structures and organization of work. Attempts are being made to determine strategies for preparing labor markets for this transformation. Meanwhile, environmental and social problems caused by globalization, demographic changes, and the tendency toward unlimited economic growth have increased concerns about the sustainability of the system. While the world labor market is already stuck with insecurity, risk, uncertainty, increased unemployment rates, and a proliferation of low-wage temporary jobs, a new wave of technological unemployment is also predicted. This paper claims the application of a utopian framework for thinking about the future of work will provide the required fundamental transformation. In this sense, Morris' contribution is significant in three areas.

The first area is that the automation of jobs in the manufacturing industry had already become widespread around the world since the 1970s and had narrowed manufacturing employment. With the fourth industrial revolution, many routines and repetitive jobs in the service sector are also expected to be digitalized. If routine and repetitive tasks can be transferred to robots and automation as expected, one can infer that creativity and originality will come to the fore. For the future world of work, the effort to be made is not in trying to preserve these jobs in order to prevent technological unemployment; instead, effort should be given to the purposes of freeing humanity from routine work so as to discover humanity's own original and creative powers. One can argue that the greatest of humanity's needs is still, as Morris suggested, the ability to reveal the self and character through artistic creation. Even though artificial intelligence has become increasingly assertive, even in arts such as musical composition and poetry, because the life and emotions that form the essence of art are unique to humans, we can still predict that this field of creation will remain in humans and that arts and crafts will play an extremely important role in human life in the future.

Secondly, by eliminating necessary work, humanity will need to break the labor-wage relation to ensure adequate living for all. With the decline of welfare states, full employment has ceased being attainable, and the ever-increasing unemployment rates have revived basic income discussions in recent years. As has been experienced during the pandemic, the need exists for an organizational variation away from the wage-based social system in order to ensure basic human rights in the world. Hu- 
manity can expect unconditional basic income practices will increase in the coming years, practices that defend not only human rights but also the productive capacity of the human being. Basic income can free people from the obligation to work for a living, and thus the concept of work can transcend the boundaries in which it has been trapped. The concept of work in the future will encompass different activities that complement human life; they will experience the pleasure of production and creation as Morris has shown us in News from Nowhere. The development of a perception of work that encompasses the diversity of human life and human creativity involves the requirement for an integrated form of life and the unity of art and work. The most important pillar of the happiness of future generations will be the ability to make artistic creation accessible to all individuals.

Finally, Morris' conceptualization of environmentally compatible labor can be said to be not only an alternative but more so a fundamental requirement for the sustainability of the world. The approach that sees nature as the antagonist of humanity and that aims to subordinate nature to the service of humanity in this contrast has done irreversible environmental damage. Consumer societies with unlimited growth trends are anything but sustainable. The fact that topics such as green jobs and environmental protection have come to the agenda in recent years indicates that awareness has increased, albeit insufficiently. Morris' ideal of harmony between nature and society should be one of the most urgent issues for the survival of humanity.

Based on Morris' conceptualization of work, thinking about today's digital technologies and social problems within the framework of utopian possibilities offers an eye-opening approach to the future. In a world where unemployment, poverty, and environmental disasters are so prevalent, these demands may seem quite utopian. This article has been written to demonstrate why the world precisely needs utopian thinking for the required social change; at the very least, efforts need to be made in this direction.

\section{References | Kaynakça}

Agamenon, O. R. E. (2014). A history of the concept of work: From physics to economics. Springer.

Beecher, J., \& Bienvenu, R. (1972). Introduction: Work in civilization. In The utopian vision of Charles Fourier: Selected texts on work, love, and passionate attraction (pp. 1-79). Beacon Press.

Bocutoğlu, E. (2012). İktisat teorisinde emeğin öyküsü: Değerin kaynağı olan emekten marjinal faydanın türevi olan emeğe yolculuk. HAK-İŞ Uluslararası Emek ve Toplum Dergisi, 1(1), 127-150.

Braham, K. (2015). Working in utopia: Locating Marx's "Realm of necessity" in the socialist futures of Bellamy and Morris (Master's thesis). The University of Vermont, The Faculty of Graduate College.

Brantlinger, P. (1975). News from nowhere: Morris' socialist anti-novel. Victorian Studies, 19(1), 35-49. 
Browne, P. L. (2018). Work, freedom, and reciprocity in William Morris' news from nowhere. The Journal of the Socialist Studies, 13(1). doi: 10.18740/ss27257

Budd, J. W. (2011). The thought of work. Cornell University - ILR Press.

Camlot, J. (2018). Morrisian spectres of working and learning in the context of the new division of labor. The Journal of the Socialist Studies, 13(1), 57-66.

Cleaver, H. (2001). Work is still the central issue! New words for new worlds. In A. C. Dinerstein \& M. Neary (Eds.), The labor debate: An investigation into the theory and reality of capitalist work (pp. 135-149). Ashgate Publishing Company.

Dinerstein, A. C., \& Neary, M. (2001). The labor debate: An investigation into the theory and reality of capitalist work. Ashgate Publishing Company.

Drinkwater, J. (1912). William Morris: A critical study. Martin Secker.

Fourier, C. (1972). The utopian vision of Charles Fourier: Selected texts on work love and passionate attraction (J. Beecher \& R. Bienvenu, Tran.). Beacon Press.

Freeman-Moir, J. (2011). Crafting experience: William Morris, John Dewey, and utopia. Utopian Studies, 22(2), 202-232. doi: 10.5325/utopianstudies.22.2.0202

Granter, E. (2009). Critical social theory and the end of work. Ashgate Publishing Limited.

Hale, P. J. (2003). Labor and the human relationship with nature: The naturalization of politics in the work of Thomas Henry Huxley, Herbert George Wells, and William Morris. Journal of the History of Biology, 36(2), 249-284.

Kinna, R. (2000). William Morris: Art, work, and leisure. Journal of the History of Ideas, 61(3), 493-512. doi: $10.2307 / 3653925$

Kumar, K. (1993). The end of socialism? The end of utopia? The end of history? In S. Bann \& K. Kumar (Eds.), Utopias and the millennium: Critical view (pp. 63-80). Reaction Books.

Kumar, K. (2002). Morris: News from nowhere, or an epoch of rest. In History of political thought. Cambridge University Press.

Kumar, K. (2005). Ütopyacılık (A. Somel, Tran.). Imge Kitabevi Yayınları.

Jacoby, R. (1999). The end of utopia: Politics and culture in an age of apathy. Basic Books.

Jacoby, R. (2005). Picture imperfect: Utopian thought for an anti-utopian age. Columbia University Press.

Levitas, R. (2001). Against work: A utopian incursion into social policy. Critical Social Policy, 21(4), 449-465.

Macdonald, B. J. (2004). William Morris and the vision of ecosocialism. Contemporary Justice Review, 7(3), 287-304).

Mannheim, K. (2008). İdeoloji ve Ütopya (M. Okyavuz, Tran.).De Ki Basım Yayım.

Marx, K. (1973). Grundrisse: Foundations of the critique of political economy (M. Nicolaus, Tran.). Penguin Books.

Marx, K. (1984). Capital (Vol. III). International Publishers.

Marx, K. (2004). Kapital, III. Cilt: Ekonomi Politiğin Eleştirisi (2 ${ }^{\text {nd }}$ ed.; A. Bilgi, Tran.). Eriş Yayınları.

McCarthy, F. (2004). Morris, William, Oxford dictionary of national biography. Retrieved from https://www. oxforddnb.com/view/10.1093/ref:odnb/9780198614128.001.0001/odnb-9780198614128-e-19322\#odnb-9780198614128-e-19322-div1-d51503e2332

Méda, D. (2010). Le travail: Une valeur en voie de disparition? Flammarion Champs Essais.

Mellor, M., Hannah, J., \& Stirling, J. (1988). Worker cooperatives in theory and practice. Open University Press.

Morris, W. (1879). Art of the people. Retrieved from https://astrofella.wordpress.com/2014/07/12/the-artof-the-people-william-morris/ 
Morris, W. (1881). Art and the beauty of the earth. Retrieved from https://www.marxists.org/archive/morris/ works/1881/earth.htm

Morris, W. (1884). Useful work versus useless toil. Retrieved from https://www.marxists.org/archive/morris/ works/1884/useful.htm

Morris, W. (1885). Attractive labour. Commonweal, Vol I, No. 5, June 1885, pp. 49-50. Retrieved from https:// www.marxists.org/archive/morris/works/1885/commonweal/06-attractive-labour.htm

Morris, W. (1888). The revival of handicraft. Retrieved from https://www.marxists.org/archive/morris/ works/1888/handcrft.htm

Morris, W. (1889). The arts and crafts of to-day. Retrieved from https://www.marxists.org/archive/morris/ works/1889/today.htm

Morris, W. (1908). News from nowhere or an epoch of rest: Being some chapters from a utopian romance (10 $0^{\text {th }} \mathrm{ed}$.). Longmans, Green, and Co.

Morris, W., \& Bax, B. E. (1886). Socialism from the root up, Commonweal. Retrieved from https://www.marxists. org/archive/morris/works/1886/sru/Socialism_From_The_Root_Up.pdf

Peksan, S. (2019, October 11-13). Concept of work in William Morris' News From Nowhere. $2^{\text {nd }}$ Erasmus International Academic Research Symposium. Paris, France, Abstract Book. Asos Yayınevi.

Peksan, S. (2021). Çalışmanın evrimi ve işin sonu. İmge Kitabevi Yayınları.

Smith, A. (2007). An inquiry into the nature and causes of the wealth of nations. Metalibri.

Spencer, D. (2009). Work in utopia: Pro-work sentiments in the writings of four critics of classical economics. In Euro. J. History of Economic Thought, 16(1), 97-122.

Stirling, J. (2002). William Morris and work as it is and as it might be. Capital \& Class, 76, 127-144. doi: $10.1177 / 030981680207600105$

Thomas, K. (1999). The Oxford book of work. Oxford University Press.

Thompson, E. P. (1976). William Morris: Romantic to revolutionary. Pantheon Books

Vallas, S. P. (2012). Work: A critique. Polity Press. 